\title{
In search of intangible connections: intellectual capital, performance and quality of life in higher education institutions
}

\author{
Eugénia de Matos Pedro ${ }^{1}$ (D) ${\text { Helena } \text { Alves }^{1} \text { (D) } \cdot \text { João Leitão }}^{1,2}$ (D)
}

Accepted: 1 November 2020 / Published online: 12 November 2020

(C) Springer Nature B.V. 2020

\begin{abstract}
This study explores the contributions of different dimensions of the intellectual capital of higher education institutions (ICHEIs) to their performance, incorporating the previously unexplored dimension of quality of life (QoL) as a performance measure, and correspondingly taking into account the connection between the Theory of Stakeholders and the Theory of Legitimacy. Applying a Structural Equation Model and the Partial Least Squares method, we present new empirical findings from a sample of 738 students and 587 lecturers/researchers from seven Portuguese public HEIs. The ICHEIs positively influence the institution's performance, through relational capital and structural capital; and QoL emerges as an important dimension of HEIs' performance standards, especially regarding students' perception of academic QoL. When HEIs understand and measure their IC, they will gain a better understanding of their core competencies, enabling a better allocation of resources and implementation of more effective strategic and operational actions.
\end{abstract}

Keywords Intangibles · Intellectual capital $\cdot$ Higher education institutions · Performance $\cdot$ Quality of life

\section{Introduction}

Recent intangible changes in higher education institutions (HEIs) triggered a growing demand for information about how HEIs manage their intellectual capital (IC) (Secundo et al. 2015).

Eugénia de Matos Pedro

eugenia@ubi.pt

1 Department of Management and Economics, NECE - Research Center in Business Sciences, University of Beira Interior, Covilhã, Portugal

2 CEG-IST- Centro de Estudos de Gestão do Instituto Superior Técnico, and ICS-Instituto de Ciências Sociais, University of Lisbon, Lisbon, Portugal 
Such reports enable the timely provision of information and assist HEI stakeholders' decisionmaking processes (Abeysekera and Guthrie 2005). HEIs must satisfy different kinds of stakeholders (Alexander and Hjortsø 2019) to gain both resources and legitimacy (Pinheiro, 2015) and advance with the structures and practices perceived as beneficial (Bitektine 2011). Accordingly, Stakeholder Theory proposes that organisations should voluntarily provide information about their intellectual, social and environmental performance (Guthrie et al. 2004).

Since the 1980s, professional management has gained relevance in European HEIs (Schimank 2005) and changes have led HEI management to a professional level in keeping with the missions shaped by stakeholders (Torre et al. 2019). For their sustainability, HEIs should set out targets that satisfy their current and potential stakeholders (Jongbloed et al. 2008; Pavičić et al. 2009; Falqueto et al. 2020), and strategic management that incorporates both competitive dynamics and stakeholders' interests (Soewarno and Tjahjadi 2020).

HEIs' main stakeholders are students and lecturers/researchers (see Mainardes et al. 2013). Students are considered human capital resources (as internal stakeholders), as well as a satisfaction-based resource, which can serve as a means of relational capital promoting recommendations (as external stakeholders). The role of students has gained increasing significance due to the payment of tuition fees, and they assume a key role in the evaluation of lecturers as a fundamental factor for the institutional image conveyed by the level of student satisfaction (Wong and Chiu 2019). This interconnection with students ensures lecturers have a fundamental role in achieving student satisfaction, especially in terms of their perceptions of teaching methods (Pedro et al. 2018). Besides teaching, lecturers are also engaged in research, administrative duties and student support (Archer 2008). Concerning researchers, the European Comission (2017) states there is great heterogeneity across member states as regards research career structures, stemming from differences in national higher education (HE) systems and different levels of economic development, affecting state budgetary allocations for research and the recruitment of researchers. Due to these facts and the goals pursued, we selected students and lecturers/researchers for this research.

Searching for intangible connections led to the still unexplored connection between the Theory of Stakeholders and the Theory of Legitimacy (Guthrie et al. 2004). The latter proposes that organisations should ensure they operate within the limits and norms of their society, and derives from the notion of a "social contract" between the organisation and the expectations of that society (Deegan 2014). Thus, HEIs also take on the role of exercising social responsibility inasmuch as this role is bound up with the "contract" signed with society, with the former being understood as behaviours that contribute to improving the quality of life (QoL) of citizens (Silva et al. 2016).

To improve organisational performance, management of tangible and intangible resources must be more professional (Hariyati et al. 2019). IC represents a combination of those intangible resources (e.g. knowledge, information, process, intellectual property). Recent studies state that without solid IC in HEIs, the strategic implementation of performance measurement systems will fail to optimise organisational performance (e.g. Tjahjadi et al. 2019). Various studies have concentrated on deepening knowledge of the different ways in which ICHEIs can influence institutional performance (e.g. Liu 2007; Lee 2010; Mumtaz and Abbas 2014; Barbosa et al. 2016; Tjahjadi et al. 2019). Traditionally, HEIs' performance levels are measured through international HEI rankings (Wedlin 2006), which play an active role in defining the academic environment and measuring HEIs' performance at a global level (González-Garay et al. 2019). 
Urdari et al. (2017) underline that the traditional HEI mission has expanded from teaching to research and incorporated a third mission entitled "contribution to society". According to Secundo et al. (2017), governments and HE policies perceive the criteria applied to assess the performance of activities interrelated with the third HEI mission as fundamental.

Some European HEIs already include stakeholders' QoL in their strategic plans as a component of strategic action able to contribute to significant increases in the levels of personal and social development among all staff (see Action Plan 2017-2021, University of Minho 2018). Therefore, QoL can be understood as the "contribution to society"(Urdari et al. 2017) and plays a prominent role in fulfilling HEIs' missions as this forms part of HEIs' social responsibilities (Silva et al. 2016).

Bearing in mind the gap detected in the literature and the limited number of third mission measurements used by international rankings, this study innovates by adding the dimension of QoL to performance measures in seeking to complement and enrich these approaches. Luger and Goldstein (1997) state that QoL can be positioned as performance indicator. The inclusion of HEI stakeholders' QoL, both as a component of the third mission and as a dimension of performance, is fundamental, but still unexplored in the literature. To offset this shortcoming, we measure QoL within the HEI environment through two measures: quality of academic life (QAL) for students and quality of work life for lecturers/researchers (QWL).

Adopting a quantitative approach, this study investigates in what way the dimensions of IC interact with HEI performance, considering the stakeholders' perspectives (students and lecturers/researchers), and addresses the following research question:

$R Q$ : What is the importance attributed by stakeholders to each of the dimensions of IC in determining the HEI's performance?

To test the RQ, the Portuguese HEIs system is chosen, for two reasons. Firstly, there was a growth in demand for HE originating in the democratisation of access to university in the revolution of April 1974, reflected in the founding of more HEIs, particularly in inland regions. Secondly, there were deep-reaching reforms brought about by government action in the 2006 to 2010 period, implemented in conjunction with a substantial increase in public financing, including a set of support and social mobility policies that enable students from less well-off backgrounds to attend HEIs (Heitor and Horta 2014). These reforms implied changes to HEIs' internal governance systems (Heitor and Horta, 2016), and alongside the participation of HEIs' governance entities, external figures of recognised renown were included (RJIES, 2007). The HE reforms in Portugal had impacts at different levels (see Heitor and Horta, 2014), among which research and internationalization. In 2016, the Portuguese government approved some guidelines to articulate the policy of internationalization of $\mathrm{HE}$, science and technology (Heitor, 2018), increasing HEIs' commitment, which is ultimately reflected in the QoL of students, opening doors to incoming and outgoing international students, as well as to international collaboration in both teaching and research activities. Direct consequences of this reinforcement are also visible in HEIs' presence in worldwide rankings, making them international references and allowing prominent HEIs to attract up-to-date knowledge, international funding and human capital to their country (Horta 2010). However, despite these reforms, the last decade saw a sharp fall in the number of HEI students, essentially due to the global financial crisis that broke out in 2008, with the intervention of the Troika (European Central Bank; European Union; International Monetary Fund) which contributed to a sharp realignment of the priorities of Portuguese HEIs (Cerdeira et al. 2019).

The current approach searches for intangible connections, aiming to make a pioneering contribution to better understanding of whether the ICHEIs impacts on performance, including 
a more subjective dimension related to the perceptions of students and lecturers/researchers as regards HEIs' social responsibility actions directed towards strengthening QoL.

To frame the research question, a brief literature review on the IC and performance of HEIs is made; three hypotheses and an operational model of analysis are presented; and finally, the conclusions, limitations and implications are formulated.

\section{Intellectual capital of HEls}

The ICHEIs join all the intangible assets, including processes, innovative capacities, patents, tacit knowledge and abilities, talents and skills of their members, recognition by society, and networks and contacts of their collaborators, among others (Ramírez and Gordillo 2014).

Incorporating new measurement and reporting models that include IC in HEIs' management is considered crucial for HEIs' sustainability (Rossi et al. 2018), and various initiatives to this end have taken place in the context of European HEIs (e.g. Lee 2010; Ramírez-Córcoles et al. 2013; Veltri et al. 2014; Secundo et al. 2015; Pedro et al. 2019). These studies consider three components of IC: human capital (HC); structural capital (SC); and relational capital $(\mathrm{RC})$, which the current study analyses as the main dimensions of ICHEIs.

\section{Performance of HEls}

HEIs are performance-oriented organisations which are observed whether for the education they provide or the funding they manage (Yu et al. 2009). Recently, international bodies have developed rankings to measure HEIs' performance (Brusca et al. 2019). The Academic Ranking of World Universities (ARWU) and the Times Higher Education World University Rankings (THE) are two of the international HEI rankings most referenced in the literature (e.g. Wende 2008; UNESCO 2013; Soh 2017). In those two rankings, HEI performance is essentially evaluated through teaching, research, internationalisation and knowledge transfer.

Institutional strategies targeted at teaching activities and performance play a significant role in improving (Skelton, 2005) and evaluating (Carlucci et al. 2019) HEIs' performance. Research activities involving all faculty members are essential, embracing scientific advances, which lead to the publication of articles, patents and international prestige (Hedjazi and Behravan 2011; Cadez et al. 2017). Internationalisation is one of the most important values in HEIs' performance standards (Bas et al. 2017). This represents the integration of international or intercultural dimensions into the functions of teaching, research and service provision (Knight 1994). In Portugal, HEIs have recently experienced intense internationalisation processes with rising results in the production and dissemination of knowledge, scientific research, international mobility and academic cooperation (Heitor and Horta 2011). Knowledge transfer becomes a strategic issue as a provider of funding for HEIs' development (Phan and Siegel 2006), including activities that generate, use, apply and/or exploit knowledge outside the academic environment (Molas-Gallart and Castro-Martinez 2007). HEIs need to monitor and evaluate their own knowledge transfer performance to identify if and when interventions are needed, and plan appropriate incentives (Rossi and Rosli, 2013).

As mentioned, QoL can be considered a dimension of performance. Hence, in this study, to measure performance from an angle more closely focused on HEIs' missions and the importance of the social responsibility component, we consider QoL within HEIs' environments. 
Recent years have seen an increasing number of studies on HEIs' QoL, specifically, the quality of academic life (QAL) for students (Pedro et al. 2016) and the quality of work life (QWL) for lecturers/researchers (Winter et al. 2000; Fontinha et al. 2018; Mohammadi and Karupiah 2019). QAL can work as an effective tool for the recommendation and attraction of students which is fundamental to ensure HEIs' capacity for survival and sustainability (Pedro et al. 2016). More satisfied students and better relations with lecturers imply better recommendation, image and reputation for HEIs. The assessment of QAL spans the feelings of global satisfaction with student life at university, which is rooted in intangible factors connected with students' perceptions and past emotional experiences of HEIs' performance (Sirgy et al. 2007). QWL can have a significant impact on staff responses, in terms of organisational identification, job satisfaction, job involvement and job effort (Sirgy et al. 2001), and thus contributes to enhancement of the institution's performance, with more motivated lecturers regarding their students and classes, and better scientific outputs that translate into more satisfied students. QWL encapsulates a form of organisational performance as this conveys the affective reactions of staff to the organisational system (Sink 1985), and considers the organisational environment according to a wide range of satisfaction needs (Sirgy et al. 2001).

Considering the absence of studies related to HEIs incorporating QoL as a dimension of performance, the current study measures this according to the following dimensions: teaching; research; internationalisation; knowledge transfer; QAL (for students); and QWL (for lecturers/researchers).

\section{Dimensions of intellectual capital and HEI performance}

IC plays an important role and can generate significant impacts on HEIs' performance (Jones et al. 2009; Mumtaz and Abbas 2014; Barbosa et al. 2016; Tjahjadi et al. 2019); has a positive effect on organisational performance (Gogan et al., 2016); plays an important role in creating an organisation's competitive advantage (Camfield et al., 2018); and contributes to HEIs' productivity levels (Taleghani et al. 2011).

$\mathrm{Lu}$ (2012) points out that the influence of ICHEIs in determining the efficiency of teaching and research is not significant, for private Taiwanese HEIs. Conversely, Mumtaz and Abbas (2014) find that ICHEIs has a significant effect on the performance of private Pakistani HEIs. Although the relationship between IC and organisational performance is supported by most previous studies, some studies still conclude that not all components of IC influence organisational performance (Tjahjadi et al., 2019).

Researchers emphasise the growing interest in the influences of IC on HEIs' performance standards and so, bearing in mind the literature review and the research question, the authors disaggregate ICHEIs and deal with the dimensions of HC, SC and RC separately.

\section{Human capital and HEls' performance levels}

HEIs' HC embraces all the most valuable human resources deployed by staff (Shehzad et al., 2014). Lecturers/researchers' HC derives from their teaching capacities and research competences (Cricelli et al. 2018). Stakeholders perceive HC as a source of internal and external knowledge creation (Barbosa et al. 2016). Human resources are the most important factor determining HEIs' higher performance (Zlate and Enache 2015), especially in HEIs more 
directed towards research and innovation (Cricelli et al. 2018). Chatterji and Kiran (2017) conclude there is no significant empirical evidence to support any direct association between the HC dimension and HEIs' performance standards in the Indian context.

$\mathrm{HC}$ is highly important to HEIs and may be (or not) directly interconnected with their levels of performance in different contexts. Thus, the first hypothesis is formulated:

$H_{1}$ : Human capital is positively and significantly related to HEIs' performance according to stakeholder perceptions.

\section{Structural capital and HEls' performance}

HEIs' SC includes all explicit knowledge interrelated with the internal organisational processes of promotion, communication and management of knowledge, which spans organisational aspects and technological resources (Pedro et al., 2019).

HEIs' SC corresponds to the knowledge that emerges from internal organisational processes (Cricelli et al., 2018), while also deriving from management of the internal relationships between technological components and organisational culture (RamírezCórcoles et al. 2011). Chatterji and Kiran (2017) address the relationship between HEI performance and IC, finding that SC has a positive effect on the performance of Indian HEIs. SC provides support for HEIs' human resources and has a positive influence on performance (Shehzad et al., 2014).

Considering the previous evidence, the second hypothesis is formulated:

$\mathrm{H}_{2}$ : Structural capital is positively and significantly related to HEIs' performance according to stakeholder perceptions.

\section{Relational capital and HEls' performance}

HEIs' RC extends across the institutional relationships built up and maintained between HEIs and non-academic partners (e.g. companies, local government, society), and stakeholders' perceptions of the institution (e.g. image, reputation, trustworthiness) (Pedro et al. 2019).

$\mathrm{RC}$ incorporates the relations between the organisation and its environment (e.g. Alcaniz et al. 2011), and these networks with external entities and organisations represent the basic component of HEIs' RC (Ramírez et al. 2007).

RC has a direct and significant effect on Indonesian HEIs' performance (Anggraini et al. 2018), as well as on Indian HEIs' performance (Chatterji and Kiran 2017). Shehzad et al. (2014) underline that HEIs' relationships with other institutions and external individuals do not produce any great impact on Pakistani HEIs' performance.

While SC is of great importance to HEIs, despite varying according to the different countries, RC can play a role in determining HEIs' performance. Thus, the third hypothesis is formulated:

$H_{3}$ : Relational capital is positively and significantly related to HEIs' performance according to stakeholder perceptions.

Considering the literature review and the research hypotheses formulated, a model of operational analysis is proposed (Fig. 1). This follows a two-step approach: firstly, a sample of students and applying QAL (Model 1); and secondly, with a sample of lecturers/researchers addressing their QWL (Model 2). 


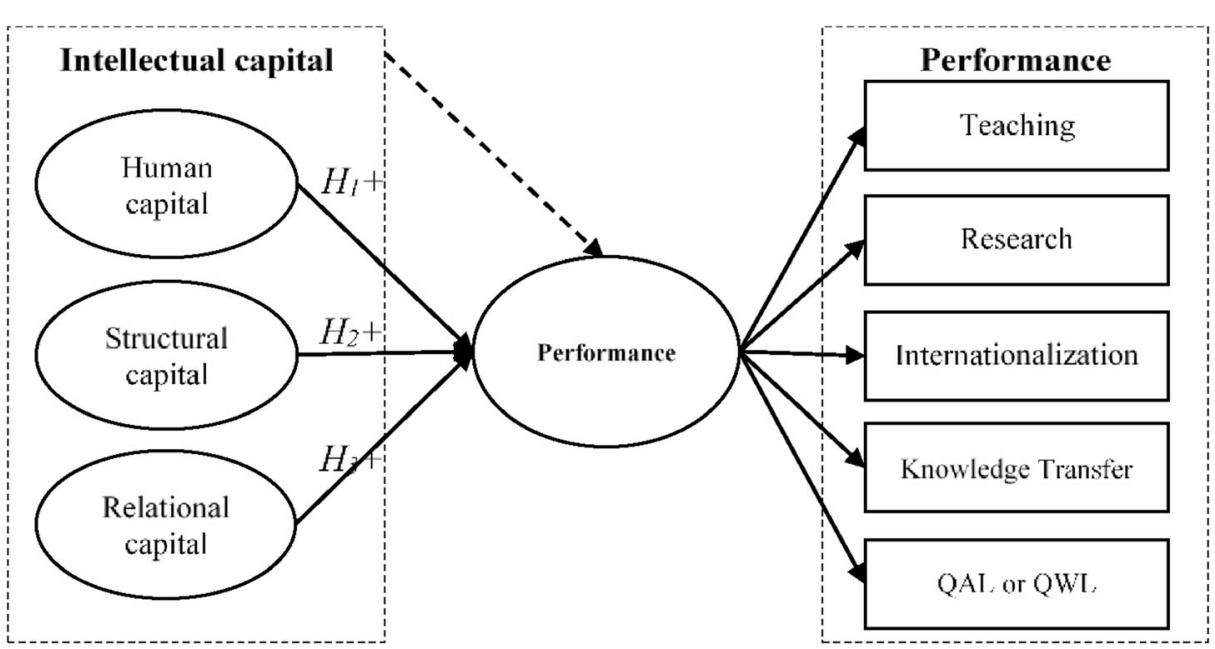

Fig. 1 Relationships between ICHEIs and HEIs' performance. Source: own elaboration

\section{Research methodology}

\section{Selection of the unit of analysis}

The study object corresponds to the universe of stakeholders (internal and external) in Portuguese state HEIs. Students enrolled in Portuguese HEIs and the lecturers/researchers form an appropriate laboratory for evaluation purposes.

Portuguese HEIs form a dual system with (126) public and private universities and (168) polytechnic institutes. The object of analysis corresponds to the universe of students and lecturers/researchers at seven Portuguese state universities, ensuring one university per region (NUTS II) (see Appendix, Table 1).

\section{Sample and data collection procedures}

Questionnaires were used for data collection, with structured and closed questions and a 7point Likert scale. Two questionnaires were produced as the QoL of students is measured through QAL (Model 1) and that of lecturers/researchers through QWL (Model 2) (see Appendix, Table 4). To ensure respondents understood the questions, a pre-test was applied in five HEIs. Model 1questionnaire was applied to 30 students in different fields of study and Model 2 questionnaire to 20 lecturers/researchers from distinct teaching/research areas. The definitive sample was collected via email. As regards the student sample, there was also the need to apply the questionnaire in the classroom as the responses received by email did not result in a representative sample. The potential for non-response bias of students' responses was assessed through the application of $t$ tests, which contrasted the initial responses to the (615) questionnaires collected online with those (123) obtained in the classroom. No significant group differences were found (see Appendix, Table 2). Data analysis was through a selected specification of a Structural Equation Model and applying the Partial Least Squares method. 


\section{Sample characterisation}

The final sample corresponds to 738 students and 587 lecturers/researchers. For more details, see Appendix, Tables 2 and 3, which detail the sample characteristics alongside the geographical locations of the HEIs, weighting by HEI, the total number of students and lecturers/ researchers in the samples; and the distribution of respondent students and lecturers/researchers by HEI, area of study, gender and age-group.

\section{Variables}

ICHEIs are measured through HC, SC and RC, according to Pedro et al. (2019). HEIs' performance is measured through (i) teaching, research, internationalisation and knowledge transfer, according to the components and indicators used by the ARWU and the THE; (ii) QAL, according to Pedro et al. (2016); and QWL, according to Sirgy et al. (2001) and Parsa et al. (2014) (see Appendix, Table 4).

\section{Presentation and discussion of the results}

Descriptive statistics and distribution of the mean values of variables were assessed and found to be quite homogeneous. The correlational relationship between the control variables was assessed and almost all correlations revealed statistical significance $(p<0.01)$, with values below or very close to 0.750 . Multicollinearity was analysed through the application of VIF (variance inflation factor) with all the values either below or very close to 3 . The common method bias $(\mathrm{CMB})$ was analysed through factorial analysis. This procedure returns the value of $41.71 \%$ for Model 1 and $30.50 \%$ for Model 2, showing that CMB does not pose a problem (Podsakoff and Organ, 1986) (see Appendix, Tables 5, 6, 7, 8).

\section{Estimating the model}

Two models were estimated: one for students (M1) and the other for lecturers/researchers (M2). As there is a second-order construct (Performance) in both models, this analysis adopts a two-step approach (Wright et al., 2012): (i) only treating the first-order constructs of M1 and M2 (models M1a and M2a) and (ii) calculating the models after incorporating the aggregate scores as indicators of second-order constructs (Models M1b and M2b).

Stage1: Estimating models M1a and M2a This stage incorporates analysis of the global model and the measurement model. All the measures consider Hair et al. (2019) as their reference.

Assessment of the global model (M1a and M2a) returned good-quality adjustment measures (SRMR $<0.08$ and $95 \%$ of the bootstrap quantile (HI95), being higher than the original values).

Assessing reflective measurement models Regarding loadings, all the indicators (M1a and M2a) present values above 0.70 , as recommended. Analysing the coefficients of internal consistency reliability ( $\mathrm{cr}$ ), as well as the Cronbach Alpha value, the results also report values of above 0.70 , and with all the variables also complying with the requirements of the DijkstraHenseler indicator $(\rho A)$ (rho_A) (>0.70). Assessment of convergent validity is through 
average variance extracted (AVE) with the results (M1a and M2a) also agreeing with the literature of reference $(\geq 0.50)$ (see Appendix, Table 9).

Discriminant validity is detected through calculating the Heterotrait-Monotrait (HTMT) ratio (HTMT < 0.90; and for conceptually different constructs: HTMT < 0.85). The results are according to the recommended values, with the exception of the interactions between research and lecturing, which return a value of HTMT $=0.927$ (see Appendix, Table 10), in M2a. As this result slightly exceeded the one recommended for HTMT, in keeping with Henseler et al. (2016), who designed studies that demonstrated how calculating the HTMT ratio provides for better detection of any lack of discriminant validity, this analysis is considered here. Bootstrapping procedures can test whether the HTMT value is significantly lower than one (Henseler et al. 2016). In both cases, no interval returns a value of one (see Appendix, Table 11), so discriminant validity did not raise any significant issues.

Assessing formative measurement models Both convergent validity and collinearity (VIF) results are ideal as their values are under 3 (see Appendix, Table 9). Regarding the statistical significance and relevance of the indicator weightings, the higher the value the better, and $p$ values $<0.05$ should not be considered. However, Hair et al. (2019) state that indicators with a non-significant weighting are statistically significant and deemed relevant whenever presenting loadings $\geq 0.50$. The non-significant indicators presenting loadings $<0.50$ were withdrawn from the model (M1a: HC8, HC9; and M2a: HC1, HC3, HC4, HC8, HC9, SC2, SC3, SC6, RC2).

Stage 2: Estimating models M1b and M2b The second-order construct (Performance) incorporates the respective scores of the first-order dimensions produced by SmartPLS. After this step, the structural model is estimated (Hair et al., 2011). For this measurement model, the procedure parallels that of Stage 1 exactly.

This confirms all the values as within the established parameters, with the exception of the loadings of «Knowledge Transfer» in M1b (0.620) and «QWL» in M2b (0.534), which return values $<0.70$. However, considering the statements of Hulland (1999) and Hair et al. (2011), that whenever there are additional indicators serving as a basis for comparison, these values may be $>0.50$, so they were retained in the model specifications.

\section{Structural model}

According to Hair et al. (2019), the results for both models confirm that the structural model presents substantial predictive relevance $\left(R^{2}\right)$, and that the exogenous construction $\left(Q^{2}\right)$ generates great predictive relevance (see Appendix, Table 12). Concerning the robustness of the path coefficients, the results display how the majority of coefficients attain a value above 0.2 (Hair et al. 2011), meaning there is robustness in the relationships, except for «human capital->performance» in both models (see Appendix, Table 13). Considering the estimated values, for the coefficients and corresponding $t$-values, there is a good adjustment of the data applied to estimate the model and test the hypotheses studied in terms of their structural relations. Figure 2 presents the final models.

Considering there is no direct effect between $\mathrm{HC}$ and performance in both models, it was verified whether $\mathrm{HC}$ generates a moderating effect on the other two pairs of relationships. This structural model aims to study the hypothetical moderating effect of the $\mathrm{HC}$ variable in terms 


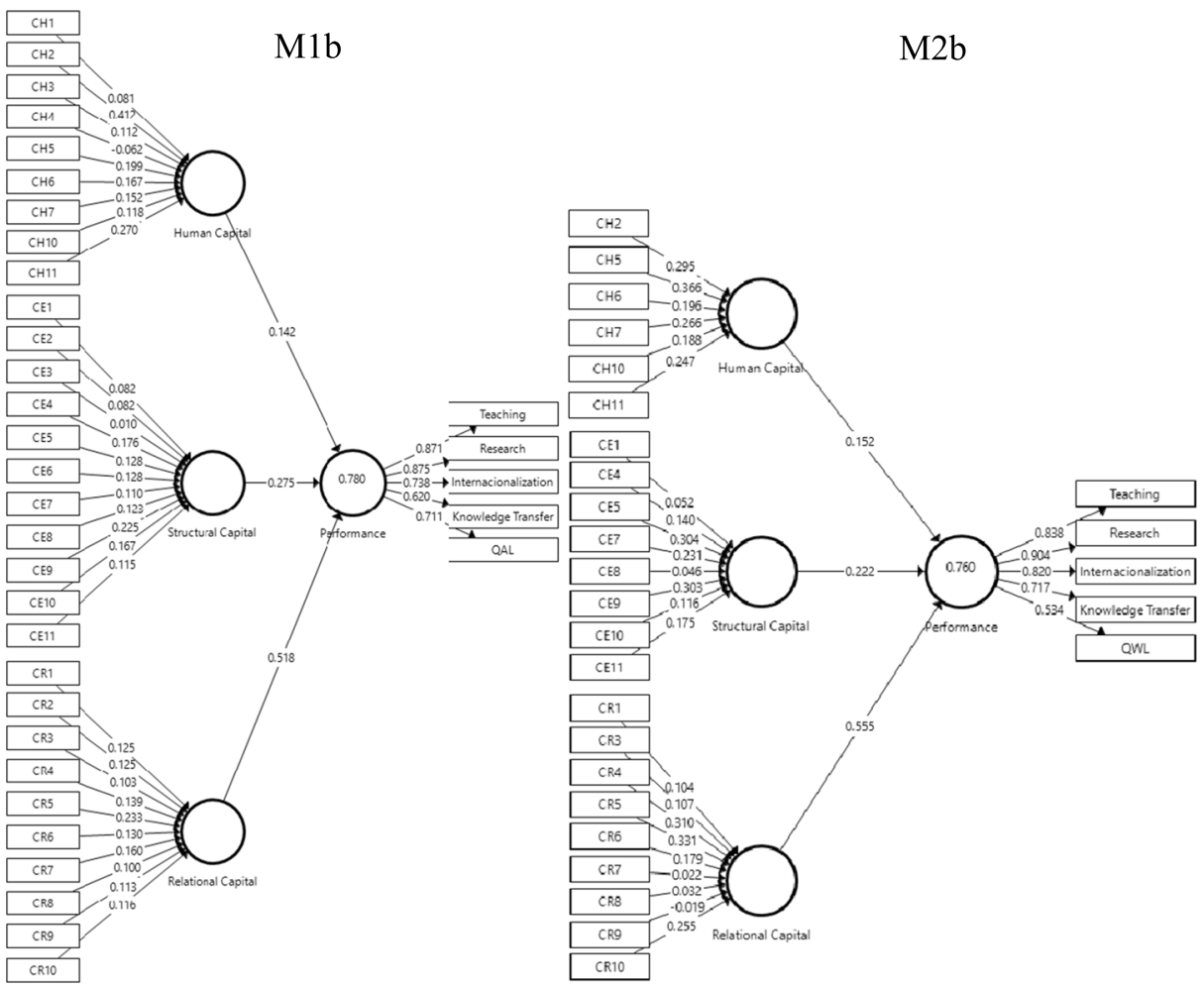

Fig. 2 Final structural models of M1b and M2b, respective weightings and loadings

of the relationship between the pairs: "Performance and SC" and "Performance and RC". Moderating effects of $\mathrm{HC}$ on «Performance», whether through $\mathrm{SC}$ or through $\mathrm{RC}$, do not obtain robustness in terms of the coefficients calculated below 0.2 , not reporting significant $t$ values $(<1.65)$. Hence, it is concluded that $\mathrm{HC}$ does not generate any moderating effect on the relationships either between performance and $\mathrm{SC}$ or between performance and $\mathrm{RC}$.

\section{Interpretation and discussion of the results}

Regarding $H_{1}$ : «Human capital is positively and significantly related to HEIs' performance according to stakeholder perceptions», despite a positive and significant relationship in both models, the coefficient lacked robustness ( $p$ value $<0.2$ ), rejecting the hypothesis. Although this result contrasts with previous studies (e.g. Barbosa et al. 2016), it can be justified by the Portuguese context, which still suffers the consequences of an economic recession with drastic cuts in HEIs' levels of financing and with $\mathrm{HC}$ undergoing equally drastic reductions in terms of the staff employed. However, this result agrees with Chatterji and Kiran (2017), who claim this is an important discovery because it provides an alternative view of new areas for HEI policy-makers to focus on, advocating that merely targeting the conventional experience of the teaching staff and research performance has become insufficient for HEIs. Institutional policies need to be increasingly open and participative in terms of the relationships formed with the external environment, students, industry and society. 
Analysing $\mathrm{HC}$ indicators returning lower values identifies how these closely relate to the professional academic and administrative experience of respondents in both models. These results may indicate the existence of gaps regarding staff recruitment, training, HC development and the possession of behavioural and ethical capacities, with possible implications for the effectiveness perceived by stakeholders.

Concerning $\mathrm{H}_{2}$ : «Structural capital is positively and significantly related to HEIs' performance, according to stakeholder perceptions», in both models the result was positive, significant and robust ( $p$ value $>0.2$ ), and the hypothesis is not rejected. This result corroborates Shehzad et al. (2014) and Chatterji and Kiran (2017). The existence of appropriate rules and regulations, and broad plans for research development, has a positive effect on HEIs' performance (Shehzad et al. 2014),

SC belongs to the organisation and should be managed according to the type and needs of each particular HEI. Martínez-Torres (2006) mentions that SC is an important component of IC because it serves as a vehicle to convert staff's personal knowledge into value. Considering the SC measurement indicators most highly valued by students and lecturers/researchers, we find those relating to the «mission, vision, values and strategic and operational processes and management and organisation of teaching activities» as the priority. Consequently, management of these aspects is essential to ensure the appropriate exploration and development of SC in Portuguese HEIs.

As regards $H_{3}$, «Relational capital is positively and significantly related to HEIs' performance according to stakeholder perceptions», this is the most important relationship in both models, aligning with the results of Shehzad et al. (2014), and not rejecting the hypothesis ( $p$ value $>0.2$ ).

In the context of Portuguese HEIs, both students and lecturers/researchers value the «Image/opinion/reputation of the HEI regionally, nationally and internationally» and the «Number of countries with collaborations developed with the HEI». So, access to institutional information is fundamental as well as the capacity to establish and run collaborative networks between stakeholders (Shehzad et al. 2014). Concerning «Student satisfaction (with studies, services, infrastructure, etc.)», students greatly value this, whereas lecturers/researchers do not. In turn, of greatest importance for lecturers/researchers is the «Number of countries with collaborations developed with the HEI». The concept of relationship is highly relevant as this interlinks with greater productivity (Cricelli et al., 2018), and thereby opens up a substantial number of opportunities to expand HEIs' RC, establishing networks with economic, political and institutional organisations, and non-academic partners, companies, government and society (Ramírez-Córcoles et al. 2011).

The results for performance and its dimensions ratify previous studies in terms of the importance devoted to teaching and research activities (e.g. Hedjazi and Behravan 2011; Carlucci et al. 2019), although they open new windows for exploring QoL as a dimension of performance. In terms of internationalisation, there is still room to improve RC, whether in terms of students or international partnerships with other HEIs. This result aligns with Heitor and Horta (2011), who state that HEIs in Portugal have adopted strategies in which RC plays a fundamental role in developing partnerships with companies and public and private institutions within technology and knowledge transfer, generating intellectual property rights (IPRs) and fostering the creation of academic spin-offs, which consolidate the third mission objectives of HEIs, as described by Rossi and Rosli (2013).

In both models, «Teaching» and «Research» remain the dimensions with the greatest influence on performance, followed by «Internationalisation». As regards «Knowledge 
transfer» and "QAL/QWL» in the student model, QAL denotes a higher value than «Knowledge transfer», while in the lecturers/researchers model, the opposite is true. Thus, QoL does indeed have importance and should be considered an alternative form of measuring HEIs' performance, as the results obtained, while differing between the two models, are both positive and significant. This difference may stem from the high levels of stress experienced by academics due to their respective labour contracts, which contribute negatively towards their QWL perceptions (Fontinha et al. 2018). Another opportunity arises from how the perceptions of QWL among lecturers/researchers emerge as lower than those observed for QAL among students. This may interrelate with how the downturn in the number of contracted academic staff took place irrespective of an increase in student numbers, and consequently the rise in the volume of work and responsibilities. Students have received greater priority in terms of ensuring their loyalty and securing recommendations for the institutions, which ensures this group feels more satisfied and hence enhancing their perceptions of QAL. These justifications resemble Winter et al. (2000), who maintain that commercial approaches to HEI management ignore the educational component and undermine the concept of a university as a place of learning and that such changes impact on the perceived QWL of academics.

Students and lecturers/researchers hold different perceptions and the communication made by HEIs to duly inform all their stakeholders about the activities they carry out internally may not be effective. The evidence obtained here contributes to verifying those results and lends greater support to Lee (2010), who proposes that a coherent model of analysis for assessing the influence of IC on HEIs' performance will enable the prediction of performance in accordance with the assessment of information gathered.

Within the scope of IC, HC returns the lowest value in both models (M1: 0.142; M2: 0.152). This difference, considering the indicators of $\mathrm{HC}$ were those presenting problems essentially in the M2 model, may underpin the supposition that neither students nor lecturers/ researchers are sufficiently informed about their system of human resources. As duly highlighted by Heitor and Horta (2014), irrespective of the reforms tending to drive higher qualification among teaching and non-teaching staff that took place in the Portuguese HEI system over the period 2006/2010, following the global financial crisis in 2008, HC experienced substantial reductions. By observing the indicators that make up $\mathrm{HC}$ in the student model (M1), the only item that returns a negative weighting is the "Weight of all teachers/ researchers in relation to total number of students" $(-0.062)$. This overloading of academic staff seems also to reflect on students, whether resulting from the number of students in the classroom or the pedagogic performance of their lecturers. Regarding the lowest indicator contribution towards $\mathrm{HC}$, in the lecturer/researcher model (M2), this identifies shortcomings in terms of the need for higher levels of qualification in pedagogic and research practices, as reflected in the lowest weighting (0.188) of the "Number of lecturers with qualifications", which may not be detached from the rise in teaching and administrative workloads and the multiplicity of functions undertaken by academic staff, which end up compromising the progressive evolution of their professional careers as actors having to secure pedagogy, supervision, research, academic management and fundraising.

\section{Conclusions, limitations and implications}

This paper focuses on stakeholders' perceptions of the influence of ICHEIs (HC, SC, RC) on HEI performance (teaching, research, internationalisation, knowledge transfer and QAL/ 
QWL), formulating three hypotheses for the purposes of testing. The results confirm that stakeholders maintain a good perception of the positive and significant relationship between ICHEIs and HEIs' performance.

To address the research question: What is the importance attributed by stakeholders to each of the IC dimensions in determining the performance of HEIs?, according to student and lecturer/researcher perceptions, this allows the inference that IC does contribute to, has a direct relationship with, and a considerably positive influence on HEI performance. This positive relationship stems firstly from $\mathrm{RC}$, and secondly from SC.

HEIs should approach their IC as a whole, but they should also pay greater attention to how $\mathrm{HC}$ may represent the dimension with the greatest room for improvement. HEIs should correspondingly deploy strategies to improve and develop their human resources while duly informing their stakeholders about such actions. HC is a powerful mechanism for creating value and can be applied in formulating organisational strategies (Liu 2007). That is the reason for giving more value to HEIs' human resources, wielding a greater influence over their own performance standards.

In the case of performance, teaching and research were the dimensions with the greatest weightings. These factors may drive diversity in the IPRs and foster the creation of academic spin-offs. Maximising the efficiency of IC through teaching and research has the potential for HEIs to significantly improve the quality and effectiveness of their efforts in both areas (Jones et al. 2009). This improvement may also foster efficiency in knowledge transfer mechanisms, where RC plays a fundamental role in developing partnerships with companies and other public and private institutions. As for internationalisation, there may also be room for improvement in terms of RC through seeking new contacts, attracting new students and establishing partnerships with other international HEIs.

IC provides the foundations for improving organisational performance and sourcing competitive advantages (Tjahjadi et al. 2019). HEIs need to pay attention to how they manage their IC, creating value for all stakeholders and developing those points that may possibly better connect to the latter's QoL. This value creation may derive from $\mathrm{HC}$ by recruiting more and better qualified lecturers/researchers; from SC, through better management of processes related to teaching; and from RC, through satisfying student needs for studies, social services and infrastructure.

Regarding limitations, these firstly derive from having eliminated some indicators from the initial models, especially from M2. Nevertheless, the final models presented return very significant and conclusive results. One possible line of research would be to undertake further empirical studies focusing on the roles played by formal and informal HC. Secondly, restricting the sample to Portuguese HEIs does not allow the generalisation of results. However, based on the Portuguese HEI system, the sample is representative, covering HEIs located in different regions (NUTS II). Similar studies might approach other countries for the purpose of providing comparative cross-country analyses. Thirdly, the fact of not having gathered information about the type of contract and professional category of lecturers/researchers. Despite including this situation at the outset, we opted to withdraw this question on the grounds of doubts that emerged in the pre-testing phase. In practice, some of the lecturers/ researchers pre-tested that belonged to smaller scale HEIs refused to respond, alleging that it would be easy to identify the respondent.

Implications are twofold. Firstly, those arising from the application of Stakeholder Theory, incorporating how transparent and high-quality information about what happens in terms of ICHEIs requires distributing to all stakeholders. The university's governance board needs to 
foster and communicate QoL better and improve the management of its own public relations, communication and public image in order to act as an interface enhancing collaborative relationships between HEIs and stakeholders. Providing equity in information access to all stakeholders, through a set of open digital platforms and tools, should be a primary concern. However, perceptions seem to vary according to the stakeholder and so IC requires periodic monitoring, and with reporting published in simple language to all, improving transparency and accountability.

Secondly, the implications associated with the Theory of Legitimacy. The social responsibility and legitimacy HEIs acquire in society mean these institutions should guide their actions in a differentiating and socially responsible way, aiming to continuously improve the QoL of all their stakeholders, through QAL and QWL, deploying open and participative mechanisms, and signalling socially responsible and ethical behaviours that reinforce their innate legitimacy. In attempting to grasp the needs and expectations of different groups of stakeholders, HEIs understand how not all wield the same influence as regards their respective legitimacy within the institution. HEIs should thus provide incentives and encourage structures and practices that these stakeholders perceive as beneficial to their own interests (Bitektine, 2011). This interaction helps to understand better the still unexplored connection between the Theory of Stakeholders and the Theory of Legitimacy, as identified by Guthrie et al. (2004).

The recent OECD (2020) report on teaching in Portugal highlights concerns about the impacts of recent policies and practices, including those enacted during the COVID 19 pandemic, on evaluation of the trade-offs between the benefits and costs of teaching institutions, including HEIs, and encapsulating mechanisms for strengthening and deepening the QoL of lecturers/researchers (QWL) and students (QAL), as well as improving the feedback channels among the participant communities.

Supplementary Information The online version contains supplementary material available at https://oi. org/10.1007/s10734-020-00653-9.

Acknowledgements The authors acknowledge the highly valuable comments and suggestions provided by the coordinating editor and two anonymous reviewers, which contributed to improving the clarity, contribution, and scientific soundness of this study.

Funding This study was funded by Fundação para a Ciência e a Tecnologia (PTDC/EGE-OGE/29926/2017).

\section{Compliance with ethical standards}

Conflict of interest The authors declare that they have no conflict of interest.

\section{References}

Abeysekera, I., \& Guthrie, J. (2005). An empirical investigation of annual reporting trends of intellectual capital in Sri Lanka. Critical Perspectives on Accounting, 16(3), 151-163. https://doi.org/10.1016/S1045-2354(03 )00059-5.

Alcaniz, L., Gomez-Bezares, F., \& Roslender, R. (2011). Theoretical perspectives on intellectual capital: a backward look and a proposal for going forward. Accounting Forum, 35(2), 104-117. https://doi. org/10.1016/j.accfor.2011.03.004. 
Alexander, I. K., \& Hjortsø, C. N. (2019). Sources of complexity in participatory curriculum development: an activity system and stakeholder analysis approach to the analyses of tensions and contradictions. Higher Education, 77(2), 301-322. https://doi.org/10.1007/s10734-018-0274-x.

Anggraini, F., Abdul-Hamid, M. A., \& Azlina, M. K. A. (2018). The role of intellectual capital on public universities performance in Indonesia. Pertanika Journal of Social Sciences and Humanities, 26(4), 24532472.

Archer, L. (2008). Younger academics' constructions of "authenticity", "success" and professional identity. Studies in Higher Education, 33(4), 385-403. https://doi.org/10.1080/03075070802211729.

Barbosa, S., Vale, J., Vale, V. T., \& Branco, M. C. (2016). Intellectual capital and performance in higher education organizations. In Proceedings of the International Conference Theory and Applications in the Knowledge Economy (pp. 670-681). Aveiro.

Bas, M.C., Boquera, M.,\& Carot, J.M.(2017). Measuring internationalization performance of higher education institutions through composite indicators. INTED2017 Proceedings, 1(March), 3149-3156. https://oi. org/10.21125/inted.2017.0815.

Bitektine, A. (2011). Toward a theory of social judgments of organizations: the case of legitimacy, reputation, and status. Academy of Management Review, 36(1), 151-179. https://doi.org/10.5465/amr.2009.0382.

Brusca, I., Cohen, S., Manes-rossi, F.,\& Nicolò, G.(2019). Intellectual capital disclosure and academic rankings in European universities Do they go hand in hand? Meditari Accountancy Research, 1-21. https://doi. org/10.1108/MEDAR-01-2019-0432.

Cadez, S., Dimovski, V., \& Zaman Groff, M. (2017). Research, teaching and performance evaluation in academia: the salience of quality. Studies in Higher Education, 42(8), 1455-1473. https://doi.org/10.1080 /03075079.2015.1104659.

Camfield, C. G., Giacomello, C. P., \& Sellitto, M. A. (2018). The impact of intellectual capital on performance in Brazilian companies. Journal of Technology Management \& Innovation, 18(3), 23-32.

Carlucci, D., Renna, P., Izzo, C., \& Schiuma, G. (2019). Assessing teaching performance in higher education: a framework for continuous improvement. Management Decision, 57(2), 461-479. https://doi.org/10.1108 /MD-04-2018-0488.

Cerdeira, L., Cabrito, B. G., \& Mucharreira, P. R. (2019). O crescimento do Ensino Superior no Portugal democrático: evolução da pós-graduação and da produção científica. EccoS-Revista Científica, 51, e14974. https://doi.org/10.5585/eccos.n51.14974.

Chatterji, N., \& Kiran, R. (2017). Relationship between university performance and dimensions of intellectual capital: an empirical investigation. Eurasian Journal of Educational Research, 71, 215-232. https:/doi. org/10.14689/ejer.2017.71.12.

Cricelli, L., Greco, M., Grimaldi, M., \& Llanes Dueñas, L. P. (2018). Intellectual capital and university performance in emerging countries: evidence from Colombian public universities. Journal of Intellectual Capital, 19(1), 71-95. https://doi.org/10.1108/JIC-02-2017-0037.

Deegan, C. M. (2014). Financial accounting theory (4th ed.). Sydney: McGraw-Hill Education Pty Ltd.. https://doi.org/10.1192/bjp.111.479.1009-a.

European Comission. (2017). MORE3 study: Support data collection and analysis concerning mobility patterns and career paths of researchers. Brussels. https://doi.org/10.2777/710643.

Falqueto, J. M. Z., Hoffmann, V. E., Gomes, R. C., \& Mori, S. S. O. (2020). Strategic planning in higher education institutions: what are the stakeholders' roles in the process? Higher Education, 79(6), 1039-1056. https://doi.org/10.1007/s10734-019-00455-8.

Fontinha, R., Van Laar, D., \& Easton, S. (2018). Quality of working life of academics and researchers in the UK: the roles of contract type, tenure and university ranking. Studies in Higher Education, 43(4), 786-806. https://doi.org/10.1080/03075079.2016.1203890.

Gogan, L., Artene, A., Sarca, I., \& Draghici, A. (2016). The impact of intellectual capital on organizational performance. Procedia - Social and Behavioral Sciences, 221, 194-202.

González-Garay, A., Pozo, C., Galán-Martín, Á., Brechtelsbauer, C., Chachuat, B., Chadha, D., et al. (2019). Assessing the performance of UK universities in the field of chemical engineering using data envelopment analysis. Education for Chemical Engineers, 29, 29-41. https://doi.org/10.1016/j.ece.2019.06.003.

Guthrie, J., Petty, R., Yongvanich, K., \& Ricceri, F. (2004). Using content analysis as a research method to inquire into intellectual capital reporting. Journal of Intellectual Capital, 5(2), 282-293. https://doi. org/10.1108/14691930410533704.

Hair, J. F., Ringle, C. M., \& Sarstedt, M. (2011). PLS-SEM: indeed a silver bullet. The Journal of Marketing Theory and Practice, 19(2), 139-152. https://doi.org/10.2753/MTP1069-6679190202.

Hair, J. F., Risher, J. J., Sarstedt, M., \& Ringle, C. M. (2019). When to use and how to report the results of PLSSEM. European Business Review, 31(1), 2-24. https://doi.org/10.1108/EBR-11-2018-0203.

Hariyati, Tjahjadi, B., \& Soewarno, N. (2019). The mediating effect of intellectual capital, management accounting information systems, internal process performance, and customer performance. International 
Journal of Productivity and Performance Management, 68(7), 1250-1271. https://doi.org/10.1108/IJPPM02-2018-0049.

Hedjazi, Y., \& Behravan, J. (2011). Study of factors influencing research productivity of agriculture faculty members in Iran. Higher Education, 62(5), 635-647. https://doi.org/10.1007/s10734-011-9410-6.

Heitor, M. (2018). Higher education, research and innovation in Portugal. Lisbon: Minister for Science, Technology and Higher Education.

Heitor, M., \& Horta, H. (2011). Science and technology in Portugal: from late awakening to the challenge of knowledge-integrated communities. In G. Neave \& A. Amaral (Eds.), Higher education in Portugal 19742009: a nation, a generation (pp. 179-226). Dordrecht: Springer. https://doi.org/10.1007/978-94-007-21357.

Heitor, M., \& Horta, H. (2014). Democratizing higher education and access to science: the Portuguese reform 2006-2010. Higher Education Policy, 27(2), 239-257. https://doi.org/10.1057/hep.2013.21.

Heitor, M., \& Horta, H. (2016). Reforming higher education in Portugal in times of uncertainty: the importance of illities, as non-functional requirements. Technological Forecasting and Social Change, 113, 146-156. https://doi.org/10.1016/j.techfore.2015.09.027.

Henseler, J., Ringle, C. M., \& Sarstedt, M. (2016). Testing measurement invariance of composites using partial least squares. International Marketing Review, 33(3), 405-431. https://doi.org/10.1108/IMR-09-2014-0304.

Horta, H. (2010). The role of the state in the internationalization of universities in catching-up countries: an analysis of the Portuguese higher education system. Higher Education Policy, 23(1), 63-81. https:/doi. org/10.1057/hep.2009.20.

Jones, N., Meadow, C., \& Sicilia, M. A. (2009). Measuring intellectual capital in higher education. Journal of Information and Knowledge Management, 8(2), 113-136.

Jongbloed, B., Enders, J., \& Salerno, C. (2008). Higher education and its communities: interconnections, interdependencies and a research agenda. Higher Education, 56(3), 303-324. https://doi.org/10.1007 /s10734-008-9128-2.

Knight, J. (1994). Internationalization: elements and checkpoints. CBIE Research No.7. In Canadian Bureau for International Education (CBIE)/Bureau Canadien de l'éducation Internationale (BCEI).

Lee, S.-H. (2010). Using fuzzy AHP to develop intellectual capital evaluation model for assessing their performance contribution in a university. Expert Systems with Applications, 37(7), 4941-4947. https://doi. org/10.1016/j.eswa.2009.12.020.

Liu, C. C. (2007). Developing measures of value creation at private universities. International Journal of Management in Education, 1(1-2), 86-99. https://doi.org/10.1504/IJMIE.2007.014379.

Lu, W. M. (2012). Intellectual capital and university performance in Taiwan. Economic Modelling, 29(4), 108189. https://doi.org/10.1016/j.econmod.2012.03.021.

Luger, M. I., \& Goldstein, H. A. (1997). What is the role of public universities in regional economic development? In R. D. Bingham \& M.R. (Eds.), Dilemmas of urban economic development (pp. 104 134). Thousand Oaks: Sage.

Mainardes, E., Alves, H., \& Raposo, M. (2013). Identifying stakeholders in a Portuguese university: a case study La identificación de los stakeholders en una universidad portuguesa. Revista de Educación, 362, 10-12. https://doi.org/10.4438/1988-592X-RE-2012-362-167.

Martínez-Torres, M. R. (2006). A procedure to design a structural and measurement model of intellectual capital: an exploratory study. Information and Management, 43(5), 617-26. https://doi.org/10.1016/j. im.2006.03.002.

Minho, U.(2018). Plano de Ação 2017-2021. Braga.Retrieved from file://C:/Users/U-Value/Downloads/ Plano_de_ac\&\%23807\%3Ba\&\%23771\%3Bo_2017-2021_-_Conselho_Geral.pdf.

Mohammadi, S., \& Karupiah, P. (2019). Quality of work life and academic staff performance: a comparative study in public and private universities in Malaysia. Studies in Higher Education, 0(0), 1-15. https://oi. org/10.1080/03075079.2019.1652808.

Molas-Gallart, J., \& Castro-Martinez, E. (2007). Ambiguity and conflict in the development of 'Third Mission' indicators. Research Evaluation., 16(4), 321-330. https://doi.org/10.3152/095820207X263592.

Mumtaz, S., \& Abbas, Q. (2014). An empirical investigation of intellectual capital affecting the performance: a case of private universities in Pakistan. World Applied Sciences Journal, 32(7), 1460-1467. https://oi. org/10.5829/idosi.wasj.2014.32.07.1251.

OECD.(2020). Education policy outlook: Portugal. Retrieved from www.oecd.org/education/policyoutlook/country-profile-Portugal-2020.pdf

Parsa, B., Idris, K. B., Samah, B. B. A., Wahat, N. W. B. A., \& Parsa, P. (2014). Relationship between quality of work life and career advancement among Iranian academics. Procedia - Social and Behavioral Sciences, 152, 108-111. https://doi.org/10.1016/j.sbspro.2014.09.164. 
Pavičić, J., Alfirević, N., \& Mihanović, Z. (2009). Market orientation in managing relationships with multiple constituencies of Croatian higher education. Higher Education, 57(2), 191-207. https://doi.org/10.1007 /s10734-008-9141-5.

Pedro, E., Leitão, J., \& Alves, H. (2016). Does the quality of academic life matter for students' performance, loyalty and university recommendation? Applied Research in Quality of Life, 11(1), 293-316. https://doi. org/10.1007/s11482-014-9367-6.

Pedro, E., Mendes, L., \& Lourenço, L. (2018). Perceived service quality and students' satisfaction in higher education: the influence of teaching methods. International Journal for Quality Research, 12(1). https://oi. org/10.18421/IJQR12.01-10.

Pedro, E., Leitão, J., \& Alves, H. (2019). The intellectual capital of higher education institutions operationalizing measurement through a strategic prospective lens. Journal of Intellectual Capital, 20(3), 355-381 JIC-072018-0117.

Phan, P. H., \& Siegel, D. S. (2006). The effectiveness of university technology transfer. Foundations and Trends in Entrepreneurship (Vol.2). https://doi.org/10.1561/0300000006.

Pinheiro, R. (2015). The role of internal and external stakeholders. In S. Schwartzman, R. Pinheiro, \& P. Pillay (Eds.), Higher education in the BRICS countries (Vol. 44, pp. 291-311). Dordhecht: Springer. https://doi. org/10.1007/978-94-017-9570-8.

Podsakoff, P. M., \& Organ, D. W. (1986). Self-reports in organizational research: problems and prospects. Journal of Management, 12(4), 531-544. https://doi.org/10.1177/014920638601200408.

Ramírez, Y., \& Gordillo, S. (2014). Recognition and measurement of intellectual capital in Spanish universities. Journal of Intellectual Capital, 15(1), 173-188. https://doi.org/10.1108/JIC-05-2013-0058.

Ramírez, Y., Lorduy, C., \& Rojas, J. A. (2007). Intellectual capital management in Spanish universities. Journal of Intellectual Capital, 8(4), 732-748.

Ramírez-Córcoles, Y., Peñalver, J., \& Ponce, Á. (2011). Intellectual capital in Spanish public universities: stakeholders' information needs. Journal of Intellectual Capital, 12(3), 356-76. https://doi.org/10.1108 /14691931111154689.

Ramírez-Córcoles, Y., Ponce, A. T., \& Vanderdonckt, J. (2013). How to respond to information needs of university stakeholders: proposal of indicators for reporting on intellectual capital. Journal of Knowledge Management, Economics and Information Technology, III(3), 1-29.

RJIES.(2007). Regime Jurídico das Instituições de Ensino Superior. Diário da República.

Rossi, F.,\& Rosli, A.(2013). Indicators of university-industry knowledge transfer performance and their implications for universities: evidence from the UK's HE-BCI survey (CIMR Research Working Paper Series No.13). Birkbeck College, University of London, London, UK. London.

Rossi, F. M., Nicolò, G., \& Polcini, P. T. (2018). New trends in intellectual capital reporting: exploring online intellectual capital disclosure in Italian universities. Journal of Intellectual Capital, 19(4), 814-835. https://doi.org/10.1108/JIC-09-2017-0119.

Schimank, U. (2005). "New public management" and the academic profession: Reflections on the German situation. Minerva, 43(4), 361-376. https://doi.org/10.1007/s11024-005-2472-9.

Secundo, G., Elena-Perez, S., Martinaitis, Ž., \& Leitner, K.-H. (2015). An intellectual capital maturity model (ICMM) to improve strategic management in European universities. Journal of Intellectual Capital, 16(2), 390-418. https://doi.org/10.1108/09564230910978511.

Secundo, G., Perez, S. E., Martinaitis, Ž., \& Leitner, K. H. (2017). An intellectual capital framework to measure universities' third mission activities. Technological Forecasting and Social Change, 123, 229-239. https://doi.org/10.1016/j.techfore.2016.12.013.

Shehzad, U., Fareed, Z., Zulfiqar, B., Shahzad, F., \& Latif, H. S. (2014). The impact of intellectual capital on the performance of universities. European Journal of Contemporary Education, 10(4), 273-280. https://oi. org/10.13187/ejced.2014.10.273.

Silva, S. M., Ruão, T., \& Gonçalves, G. (2016). O Desafio Da Comunicação Estratégica nas Instituições de Ensino Superior: Estudo do Papel da Comunicação na Promoção da Sua Missão Social. Revista Comunicando, 5(1), 218-242.

Sink, D. S. (1985). Productivity management: planning, evaluation, control and improvement. New York: John Wiley and Sons, Inc..

Sirgy, M. J., Efraty, D., Siegel, P., \& Lee, D. A. (2001). New measure of quality of work life (Qowl) based on need satisfaction and spillover theories. Social Indicators Research, 55(3), 241-302.

Sirgy, M. J., Grzeskowiak, S., \& Rahtz, D. (2007). Quality of College Life (QCL) of students: developing and validating a measure of well-being. Social Indicators Research, 80(2), 343-60. https://doi.org/10.1007 /s11205-005-5921-9.

Skelton, A. (2005). Understanding teaching excellence in higher education: towards a critical approach. London: Routledge. 
Soewarno, N.,\& Tjahjadi, B.(2020). Mediating effect of strategy on competitive pressure, stakeholder pressure and strategic performance management (SPM): evidence from HEIs in Indonesia. Benchmarking, (July). https://doi.org/10.1108/BIJ-06-2019-0292.

Soh, K. (2017). The seven deadly sins of world university ranking: a summary from several papers. Journal of Higher Education Policy and Management ISSN, 39(1), 104-115. https://doi.org/10.1080/1360080 X.2016.1254431.

Taleghani, M., Shirsavar, H. A., \& Gashti, G. B. (2011). Determine of the relationship between dimensions of intellectual capital and productivity of education organization of Guilan Province. Australian Journal of Basic and Applied Sciences, 5(8), 1456-60.

Tjahjadi, B., Soewarno, N., Astri, E., \& Hariyati, H. (2019). Does intellectual capital matter in performance management system-organizational performance relationship? Experience of higher education institutions in Indonesia. Journal of Intellectual Capital, 20(4), 533-554. https://doi.org/10.1108/JIC-12-2018-0209.

Torre, E. M., Rossi, F., \& Sagarra, M. (2019). Who benefits from HEIs engagement? An analysis of priority stakeholders and activity profiles of HEIs in the United Kingdom. Studies in Higher Education, 44(12), 2163-2182. https://doi.org/10.1080/03075079.2018.1479847.

UNESCO. (2013). Rankings and accountability in higher education: uses and misuses. In P. Marope, P. Wells, \& E. Hazelkorn (Eds.), Education on the move (Vol. 235). United Nations educational.

Urdari, C., Farcas, T. V., \& Tiron-Tudor, A. (2017). Assessing the legitimacy of HEIs' contributions to society: the perspective of international rankings. Sustainability Accounting, Management and Policy Journal, 8(2), 191-215. https://doi.org/10.1108/SAMPJ-12-2015-0108.

Veltri, S., Mastroleo, G., \& Schaffhauser-Linzatti, M. (2014). Measuring intellectual capital in the university sector using a fuzzy logic expert system. Knowledge Management Research and Practice, 12(2), 175-192. https://doi.org/10.1057/kmrp.2012.53.

Wedlin, L.(2006). “Ranking business schools: forming fields, identities and boundaries". International Management Education. Abingdon: Edward Elgar publishing limited.

Wende, M. (2008). Rankings and classifications in higher education: a European perspective. Higher Education, 23, 49-71. https://doi.org/10.1007/978-1-4020-6959-8.

Winter, R., Taylor, T., \& Sarros, J. (2000). Trouble at mill: quality of academic worklife issues within a comprehensive Australian university. Studies in Higher Education, 25(3), 279-294. https://doi. org/10.1080/713696158.

Wong, B., \& Chiu, Y. L. T. (2019). Let me entertain you: the ambivalent role of university lecturers as educators and performers. Educational Review, 71(2), 218-233. https://doi.org/10.1080/00131911.2017.1363718.

Wright, R., Campbell, D., Thatcher, J., \& Roberts, N. (2012). Operationalizing multidimensional constructs in structural equation modeling: recommendations for IS research. Communications of the Association for Information Systems Volume, 30(23), 367-412.

Yu, M. L., Hamid, S., Ijab, M. T., \& Soo, H. P. (2009). The e-balanced scorecard (e-BSC) for measuring academic staff performance excellence. Higher Education, 57(6), 813-828. https://doi.org/10.1007/s10734009-9197-x.

Zlate, Ș., \& Enache, C. (2015). The interdependence between human capital and organizational performance in higher education. Procedia-Social and Behavioral Sciences, 180(November 2014), 136-143. https://doi. org/10.1016/j.sbspro.2015.02.096.

Publisher's note Springer Nature remains neutral with regard to jurisdictional claims in published maps and institutional affiliations. 